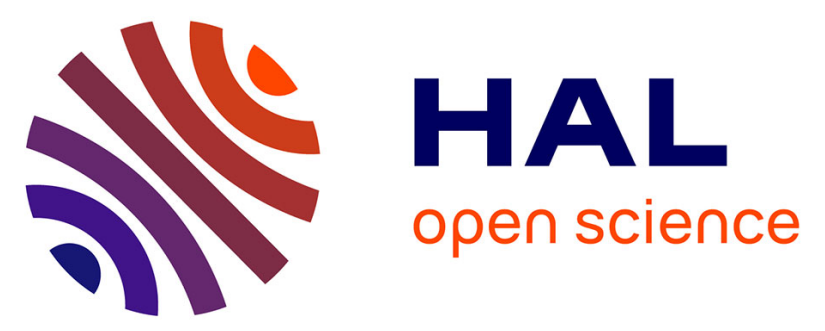

\title{
Oxidation of Ni-Rich Mangrove Sediments after Isolation from the Sea (Dumbea Bay, New Caledonia) : Fe and Ni Behavior and Environmental Implications
}

Vincent Noël, Farid Juillot, Guillaume Morin, Cyril Marchand, Georges Ona-Nguema, Eric Viollier, François Prévot, Gabrielle Dublet, Fabien Maillot, Ludovic Delbes, et al.

\section{To cite this version:}

Vincent Noël, Farid Juillot, Guillaume Morin, Cyril Marchand, Georges Ona-Nguema, et al.. Oxidation of Ni-Rich Mangrove Sediments after Isolation from the Sea (Dumbea Bay, New Caledonia): Fe and Ni Behavior and Environmental Implications. ACS Earth and Space Chemistry, 2017, 1 (8), pp.455-464. 10.1021/acsearthspacechem.7b00005 . insu-02888779

\section{HAL Id: insu-02888779 \\ https://hal-insu.archives-ouvertes.fr/insu-02888779}

Submitted on 6 Aug 2020

HAL is a multi-disciplinary open access archive for the deposit and dissemination of scientific research documents, whether they are published or not. The documents may come from teaching and research institutions in France or abroad, or from public or private research centers.
L'archive ouverte pluridisciplinaire HAL, est destinée au dépôt et à la diffusion de documents scientifiques de niveau recherche, publiés ou non, émanant des établissements d'enseignement et de recherche français ou étrangers, des laboratoires publics ou privés. 


\title{
Oxidation of Ni-Rich Mangrove Sediments after Isolation from the Sea (Dumbea Bay, New Caledonia): Fe and Ni Behavior and Environmental Implications
}

\author{
Vincent Noël, ${ }^{* \dagger, *(1)}$ Farid Juillot, ${ }^{\dagger, \S}$ Guillaume Morin, ${ }^{\dagger}$ Cyril Marchand, ${ }^{\dagger, \S}$ Georges Ona-Nguema,
} Eric Viollier," François Prévot, ${ }^{\|}$Gabrielle Dublet, ${ }^{\dagger, \perp}$ Fabien Maillot, ${ }^{\dagger}$ Ludovic Delbes, ${ }^{\dagger}$ Gregory Marakovic, ${ }^{+}$John R. Bargar, ${ }^{\#}$ and Gordon E. Brown, Jr. ${ }^{\perp, \#}$

†Institut de Minéralogie, de Physique des Matériaux et de Cosmochimie (IMPMC), UMR 7590 CNRS, UMR 206 IRD, MNHN, Université Pierre et Marie Curie (UPMC), 4 place Jussieu, 75005 Paris, France

${ }^{\ddagger}$ Koniambo Nickel SAS (KNS), B.P.679, 98860 Koné, Nouvelle Calédonie

${ }^{\S}$ Institut de Recherche pour le Développement (IRD), UMR 206 IRD IMPMC, 98848 Nouméa, Nouvelle-Calédonie

"Equipe de Biogéochimie Environnementale de l’Institut de Physique du Globe de Paris (IPGP), UMR 7154 IPGP, Université Paris Diderot, Bâtiment Lamark, Case Postale 7052, 75205 Paris cedex 13, France

${ }^{\perp}$ Surface and Aqueous Geochemistry Group, Department of Geological Sciences, School of Earth, Energy, and Environmental Sciences, Stanford University, Stanford, California 94305-2115, United States

\# Department of Photon Science and Stanford Synchrotron Radiation Lightsource, SLAC National Accelerator Laboratory, 2575 Sand Hill Road, MS 69, Menlo Park, California 94025, United States

\begin{abstract}
Formation of Fe-sulfides in anoxic horizons of mangrove sediments makes this ecosystem a potential long-term sink for metal contaminants in the intertropical region. Increasing anthropogenic pressure on coastal areas can alter the physicochemical of mangrove sediments by modifying their redox state, affecting directly the rate of Fe-sulfides that mediate accumulation of metal contaminant. Here, we show that isolation from the sea, due to land use planning, directly modify the redox state of mangrove sediments from reducing condition to oxidizing condition, affecting the stability of Ni-accumulating Fe-sulfides. Unusual suboxic/oxic conditions are indeed observed at intermediate depths in these mangrove sediments and favor the oxidative dissolution of Ni-pyrite $\left(\mathrm{Fe}_{1-x} \mathrm{Ni}_{x} \mathrm{~S}_{2}\right)$ that initially formed under anoxic/suboxic conditions. This reaction leads to a significant release of aqueous $\mathrm{HS}^{-}, \mathrm{Fe}^{2+}$ and $\mathrm{Ni}^{2+}$ at the redox boundary.

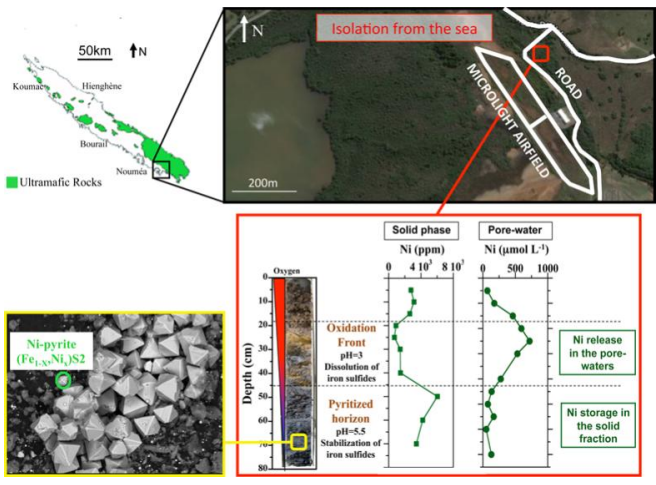
$\mathrm{HS}^{-}$and $\mathrm{Fe}^{2+}$ oxidize into $\mathrm{SO}_{4}{ }^{2-}$ and $\mathrm{Fe}^{3+}$ and precipitate as schwertmannite $\left(\mathrm{Fe}_{8} \mathrm{O}_{8}(\mathrm{OH})_{6} \mathrm{SO}_{4}\right)$, leading to acidification of the pore-waters. Meanwhile, aqueous $\mathrm{Ni}^{2+}$ is mostly leached downward in the underlying anoxic layers of the sediment where it sorbs at the surface of pyrite and/or incorporates in the structure of newly formed pyrites. These results emphasize the potential of Fe-sulfides for mitigating the impact of the oxidation of former Ni-rich mangrove sediments, as long as the anoxic conditions are preserved at depth. This assumption can be expanded to other divalent metals and should be applicable to a larger set of mangrove ecosystems worldwide.
\end{abstract}

KEYWORDS: Mangrove sediments, oxidation processes, iron and nickel, X-ray absorption spectroscopy, anthropogenic pressure, pyrite

\section{INTRODUCTION}

Mangroves cover more than $70 \%$ of tropical and subtropical coastlines and act as ecological filters between land and sea, 1,2 especially for metals. ${ }^{3,4}$ However, due to their persistence, potential toxicity, and bioavailability, the inputs from natural or anthropogenically impacted watersheds of various metals such as $\mathrm{Cu}, \mathrm{Cd}, \mathrm{Cr}, \mathrm{Pb},{ }^{5,6} \mathrm{Ni}^{7} \mathrm{~Pb}, \mathrm{~V}$, and $\mathrm{Zn}^{8}$ can represent a major potential threat to mangrove biodiversity. ${ }^{9-11}$ The accumulation of metals in mangrove sediments is partly attributed to the ability of these sediments to efficiently trap suspended materials from the water column ${ }^{12}$ and to their large concentrations of dissolved or solid organic matter and of fine-grained mineral particles with large specific surface areas (e.g., clay minerals) both of which are known for their strong affinity for metals. ${ }^{13-16}$ Furthermore, recent studies suggest 
that bottom-water oxygen concentration is one of the key factors governing stability and lability of metals complexes in the underneath sediment. ${ }^{17,18}$ More specifically, the organicrich mangrove sediments are redox-stratified with more reducing conditions at depth in response to organic matter decomposition and sulfate reduction processes. ${ }^{19,20}$ Such biogeochemical cycles were emphasized in the mangrove sediments to play a direct role in iron mineral transformations (dissolution/precipitation of sulfides and oxides). Consequently, the chemical forms of Fe exhibit dramatic variability tied to redox gradients generated by both the topographic position across the intertidal zone and the depth within the sediments. $^{21,22}$ As a result of this redox stratification, the mineral transformations enhance with increasing depth ${ }^{21,22}$ and therefore can also play an indirect role on the redistribution and mobility of metals associated with minerals and organic matter inherited from detrital sedimentation. ${ }^{23}$ The increasing precipitation of Fe-sulfide minerals with increasing depth has been found to efficiently incorporate the remobilized metals during the chemical and mineral transformations of sulfidic environments. $^{23-29}$ The relative stability of Fe-sulfides in the anoxic horizons of mangrove sediments can then lead mangrove ecosystems to act as long-term sinks for metals, provided that reoxidation processes are limited. ${ }^{23,30-33}$

The formation and preservation of Fe-sulfides in mangrove sediment horizons can be considered as a key factor that control metal scavenging at the land-sea interface in tropical regions. However, in the context of increasing demographic pressure and urbanization of coastal areas, artificial isolation of mangroves from the sea can significantly modify their biogeohydrological functioning. ${ }^{29}$ In particular, shortening of the flooding period can result in reoxidation of the upper horizons of mangrove sediments and subsequent destabilization of Fesulfides. For example, the formation of Coastal Lowland Acid Sulfate Soils (CLASS) $)^{31-33}$ has been demonstrated to counteract the ability of pyritization to sequester metals in mangrove sediments. $^{9,30,32,33}$ Such an issue is potentially of major importance in New Caledonia, where a large fraction of mangroves accumulate metal-rich particles due to intense erosion of massive lateritic deposits enriched in transition metals such as $\mathrm{Fe}, \mathrm{Ni}$, but also to a lesser extent $\mathrm{Cr}, \mathrm{Co}$, and $\mathrm{Mn}^{34-36}$ because of the tropical climate ${ }^{7}$ and local mining. ${ }^{37}$

In the present study, we have evaluated the extent to which $\mathrm{Fe}$ and $\mathrm{Ni}$ can be mobilized by the reoxidation of a former mangrove stand now isolated from the sea. The composition of pore-waters along a representative sediment core is interpreted in the context of the solid-state speciation of $\mathrm{Ni}$ and $\mathrm{Fe}$, which was determined using X-ray absorption spectroscopy (XAS) and mineralogical analysis.

\section{EXPERIMENTAL SECTION}

2.1. Field Site and Sampling of Solid Sediment and Pore-Waters. The mangrove sediments investigated are located on the west coast of the New Caledonia main island $\left(20^{\circ} \mathrm{S}-23^{\circ} \mathrm{S}\right)$, which has a semiarid tropical climate. Sampling was performed at the beginning of the dry season in June 2009 in a former mangrove stand that developed at the mouth of the Dumbea River. The catchment of this river is composed of ultramafic rocks and lateritic soils ${ }^{38}$ that have been mined from the end of the 19th century to the middle of the 20th century for their large $\mathrm{Fe}$ and $\mathrm{Ni}$ contents. The former mangrove stand initially developed as an Avicennia marina forest, the second major mangrove species found across the whole island. ${ }^{39}$ It has been artificially isolated from the sea after road construction about 10 years ago, and it is now covered with the herbaceous species Acrostichum aureum (Figure SI-1).

After extraction of a $70 \mathrm{~cm}$ long sediment core with an Eijkelkamp gouge auger, sediment samples were collected at fineer vertical resolution $(\sim 5 \mathrm{~cm})$, along with a segment of neighboring over- and underlying sediment, under nitrogen flow and preserved from oxidation in $\mathrm{N}_{2}$-purged serum vials (crimp-sealed with rubber stoppers). All samples were immediately stored in the dark at $3{ }^{\circ} \mathrm{C}$ and shipped on ice to the laboratory where they were introduced in a glovebox in $5 \%$ $\mathrm{H}_{2} / 95 \% \mathrm{~N}_{2}$ atmosphere in order to be vacuum-dried.

Pore-waters were extracted from a second sediment core collected in a PVC tube with Rhizon soil moisture samplers. ${ }^{40}$ After being collected in PVC tube, each sediment core was immediately placed in a field glovebag filled with $\mathrm{N}_{2}$ atmosphere. The soil moisture samplers were then directly inserted into the core through holes into the PVC tube and they were connected to a syringe using luer-lock fittings. Around $15 \mathrm{~mL}$ of pore-water was collected for a section of core of $150 \mathrm{~cm}^{3}$, and each pore-water volume was divided into two aliquots. The first aliquot was immediately introduced in liquid nitrogen prior to analyzing the dissolved iron and sulfur speciation, as well as quantifying total sulfate and chloride concentrations. The second aliquot was placed in acid-cleaned sealed polypropylene tubes, acidified to $\mathrm{pH} 2$ with Suprapur $\mathrm{HNO}_{3}$, and stored in a cold room $\left(T=4{ }^{\circ} \mathrm{C}\right)$ until quantification of total dissolved $\mathrm{Fe}$ and $\mathrm{Ni}$. Pore-water salinity, $\mathrm{pH}$, and redox potential ( $\mathrm{Eh}$ ) were measured in the field. Detailed information on sampling and analytical procedures is available in the Supporting Information (SI).

2.2. Chemical Composition and Mineralogical Analyses. All analyses for dissolved species were performed at the Institut de Physique du Globe (IPGP). Dissolved Fe and $\mathrm{Ni}$ concentrations were respectively measured in the pore-waters by inductively coupled plasma-atomic emission spectroscopy (ICP-AES) with an ICAP (ThermoFisher Scientific) spectrometer after 100 times dilution and by high-resolution inductively coupled plasma - mass spectrometry (HR-ICP-MS) with a Element2 (Thermofisher Scientific) equipped with an integrated FAST (ESI) injection system after 300 times dilution. Certified reference materials (SLRS4) were intercalated during the analytical series. Aqueous $\mathrm{Fe}^{2+}$ and $\mathrm{H}_{2} \mathrm{~S}$ were measured in the pore-waters by colorimetric methods using a SpectroDirect (AQUALYTIC) spectrophotometer. These analyses were carried out in a glovebag filled with $\mathrm{N}_{2}$ atmosphere, $48 \mathrm{~h}$ after collection. Finally, sulfate and chloride concentrations were quantified by ion chromatography with a Dionex IonPac AS12 analytical column.

Bulk concentrations of major $(\mathrm{Si}, \mathrm{Mg}, \mathrm{Fe}, \mathrm{Al}, \mathrm{K}, \mathrm{Ca}$ ) and trace $(\mathrm{Ni}, \mathrm{Cr}, \mathrm{Mn})$ elements in the dried solid samples were measured at the Institut de Mineralogie, de Physique des Materiaux et de Cosmochimie (IMPMC) with a XEPOS (Spectro X Lab) X-ray fluorescence spectrometer equipped with a $\mathrm{Pd}$ cathode and operating at $50 \mathrm{kV}$ and $40 \mathrm{~mA}$. Total organic carbon (TOC) in solid sediments was determined at IPGP with a SSM-5000A combined with TOC-L Series analyzer on powdered samples. Mineralogical compositions of the solid samples were determined by powder X-ray diffraction (XRD) using an X'Pert Pro (Panalytical) diffractometer equipped with an $X^{\prime}$ celerator detector, and scanning electron microscopy (SEM) coupled with energy dispersive X-ray spectroscopy (EDXS) using a GEMINI Ultra55 (ZEISS) 
Field Emission Gun Scanning Electron Microscope. All of these analytical procedures are detailed in the Supporting Information.

2.3. Fe and Ni K-Edge XAS Data Collection and Analyses. Fe and Ni K-edge X-ray absorption spectra of the sediments were collected at $10 \mathrm{~K}$ on beamline $11-2$ at the Stanford Synchrotron Radiation Lightsource, California, U.S.A. Fe K-edge XAS data were collected in transmission detection mode, whereas $\mathrm{Ni}$ K-edge XAS data were collected in fluorescence detection mode using a Canberra high-throughput Ge 30-element solid-state array detector. The energy of the Xray beam was calibrated by setting the first inflection point in (i) the Fe K-edge spectrum of a Fe foil to $7112 \mathrm{eV}$ and (ii) the $\mathrm{Ni}$ K-edge spectrum of a $\mathrm{Ni}$ foil $8333 \mathrm{eV}$. For all samples, only 2 scans were needed for Fe K-edge data, whereas 6 to 17 scans were needed to achieve an acceptable signal/noise ratio for $\mathrm{Ni}$ K-edge. For each bulk sediment sample, Fe and Ni K-edge XAS data were averaged and normalized using the ATHENA software package. ${ }^{41} \mathrm{Fe}$ and Ni K-edge EXAFS spectra were then background-subtracted from these normalized data using the XAFS code. $^{42}$ Fourier transforms (FT) of these EXAFS spectra were obtained by fast Fourier transformation of the $k^{3}$ weighted experimental $\chi(k)$ function using a Kaiser-Bessel window with the Bessel weight fixed at 2.5.

$\mathrm{Fe}$ and Ni K-edge EXAFS spectra of all sediment samples were least-squares fit by linear combination (LC-LS fitting) of experimental EXAFS spectra of appropriate model compounds selected from a large database, $22,23,36,43$ as detailed in Supporting Information. Briefly, principal component analysis $\left(\mathrm{PCA} ;{ }^{44,45}\right)$ was performed with the SIXPACK code $^{46}$ prior to LC-LS fitting in order to estimate the minimum number of components necessary to fit the Fe K-edge EXAFS spectra of our mangrove sediments ${ }^{47}$ (Table SI-3). Model compounds for the LC-LS fitting procedure were then selected by target transform (TT) analysis of our large set of Fe K-edge EXAFS spectra from natural and synthetic model compounds (Table SI-4). Ni K-edge model compounds were selected on the basis of our previous PCA-TT and LC-LS analysis of a large set of mangrove sediment samples from New Caledonia. ${ }^{23}$ LC-LS fits were performed with custom-built software based on the Levenberg-Marquardt minimization algorithm ${ }^{23}$ and fit quality was estimated using an R-factor parameter $(R f)$ of the following form: $R f=\sum\left[y_{\exp }-y_{\text {calc }}\right]^{2} / \sum\left[y_{\exp }\right]^{2}$. The accuracy of this fitting procedure ranges between $\pm 5 \%$ and $\pm 25 \%$ of the stated values for each individual contribution, and the detection limit for minor species is estimated to be $\sim 10 \%$. Contributions below this limit are not considered to be statistically significant. $^{48}$

\section{RESULTS}

3.1. Environmental Parameters. The measured physicochemical parameters, including redox potential, $\mathrm{pH}$, and salinity, are reported as a function of depth in Figures 1 and 2 and Table SI-1. Salinity is around 21 for the first $20 \mathrm{~cm}$ and increases to 40 below $45 \mathrm{~cm}$ (Figure 1a; Table SI-1). Eh values increase from $270 \mathrm{mV}$ to $495 \mathrm{mV}$ within the first $30 \mathrm{~cm}$ of the mangrove sediment core and then progressively decrease to their lowest value (i.e., about $100 \mathrm{mV}$ ) at $65 \mathrm{~cm}$. Although acidic along the entire core studied, the $\mathrm{pH}$ values show an evolution opposite to that of $\mathrm{Eh}$ values. These $\mathrm{pH}$ values decrease from 5.5 to 3 within the first $30 \mathrm{~cm}$ of sediment and then progressively increase to their highest value (i.e., about 6) at $65 \mathrm{~cm}$ (Figure 2b; Table SI-1). Finally, total organic carbon

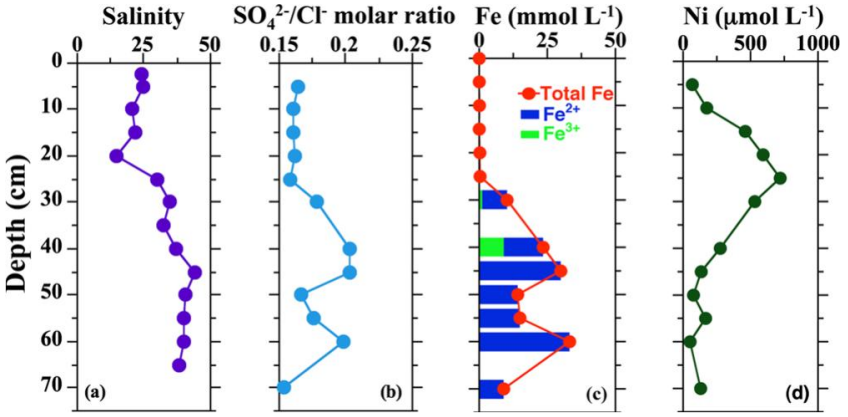

Figure 1. Vertical changes of (a) the salinity (purple line), (b) the dissolved $\mathrm{SO}_{4}{ }^{2-} / \mathrm{Cl}^{-}$molar ratio (blue line), (c) the total dissolved $\mathrm{Fe}$ concentration (red line), and (d) the total dissolved Ni concentration (green line) as a function of depth in the pore-waters of the studied mangrove sediments. The blue and green bars in (c) represent the proportion of dissolved $\mathrm{Fe}^{2+}$ and $\mathrm{Fe}^{3+}$, respectively. All dissolved $\mathrm{SO}_{4}^{2-} / \mathrm{Cl}^{-}$molar ratios measured in the pore-water were greater than those of seawater $\left(0.05^{40}\right)$. Depths below ground surface are noted numerically.

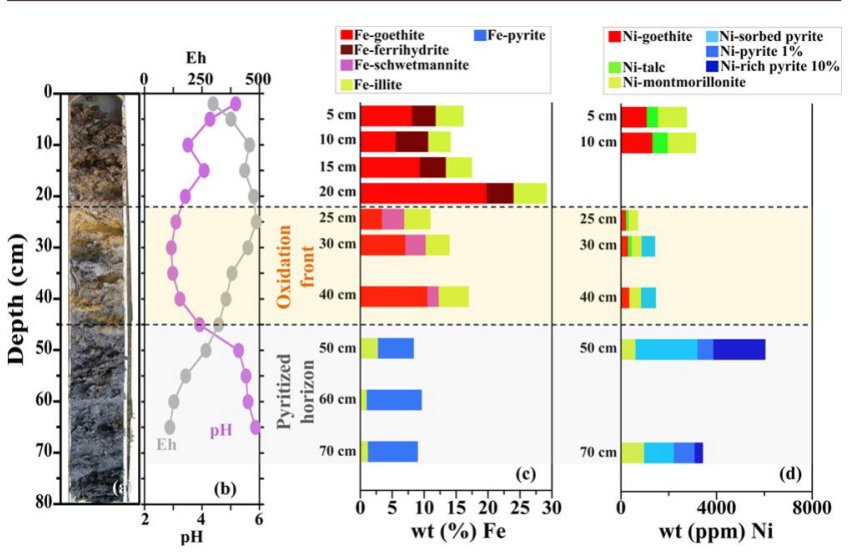

Figure 2. Evolution of iron and nickel solid-phase speciation and of physicochemical parameters as a function of depth in the mangrove sediment core studied. (a) Picture showing the vertical changes in the sediment color; (b) vertical profiles of $\mathrm{pH}$ (pink line) and Eh (gray line) in the pore-waters; (c) Fe speciation derived from LC-LS fit of $\mathrm{Fe}$ K-edge EXAFS data; and (d) Ni speciation derived from $\mathrm{Ni}$ K-edge EXAFS data. Proportions of the fit components have been normalized to the total concentration of $\mathrm{Fe}$ or $\mathrm{Ni}$ in the solid fraction. Depths below ground surface are noted numerically. The brown shading shows the location of the oxidation front and the gray shading shows the location of the pyritized horizon.

(TOC) ranges between $2 \%$ and $9 \%$ for the sediment core as a function of depth (Table SI-1).

3.2. Dissolved $\mathrm{Fe}, \mathrm{S}$, and $\mathrm{Ni}$ in the Pore-Waters. The sulfate $\left(\mathrm{SO}_{4}{ }^{2-}\right)$ to chloride $\left(\mathrm{Cl}^{-}\right)$molar concentration ratio in the pore-waters follows the vertical change of the dissolved iron concentration. With an average value of 0.16 from 0 to $20 \mathrm{~cm}$, this ratio increases from 25 to $45 \mathrm{~cm}$ where it reaches a value of 0.2 (i.e., four times that of seawater; ${ }^{51}$ ) and then decreases slightly to a value of 0.16 , with a maximum of 0.2 at $60 \mathrm{~cm}$ (Figure 1b; Table SI-2). Total dissolved iron is roughly constant around $0.14 \mathrm{mmol} \mathrm{L}^{-1}$ from 0 to $20 \mathrm{~cm}$ (Figure 1c; Table SI-2), then it increases from $25 \mathrm{~cm}$ depth to reach a maximum of $<30 \mathrm{mmol} \mathrm{L} \mathrm{L}^{-1}$ at $45 \mathrm{~cm}$ depth and $33 \mathrm{mmol} \mathrm{L}$ at $60 \mathrm{~cm}$ depth, and finally drops to $<10 \mathrm{mmol} \mathrm{L}^{-1}$ at $70 \mathrm{~cm}$ depth. Colorimetric measurements indicate that aqueous $\mathrm{Fe}$ consists mainly of aqueous $\mathrm{Fe}^{2+}$ species, although the porewaters between 30 and $40 \mathrm{~cm}$ also contain $\sim 10 \mathrm{mmol} \mathrm{L}^{-1}$ of 
dissolved $\mathrm{Fe}$ (III) species. A large part of the $\mathrm{Fe}^{3+}$ in the dissolved phase likely corresponds to colloidal Fe-oxyhydroxide and/or $\mathrm{Fe}$ organic complexes because the solubility of $\mathrm{Fe}$ oxyhydroxides and oxyhydroxysulfates does not exceed $0.1 \mathrm{mM}$ at $\mathrm{pH} 3 .^{49,50}$ In contrast to total dissolved $\mathrm{Fe}$ and $\mathrm{S}$ concentration, total dissolved $\mathrm{Ni}$ concentration increases from $69 \mu \mathrm{mol} \mathrm{L}^{-1}$ to a high of $\sim 719 \mu \mathrm{mol} \mathrm{L}{ }^{-1}$ from surface to $25 \mathrm{~cm}$, then it decreases from 25 to $45 \mathrm{~cm}$ down up an average of 112 $\mu \mathrm{mol} \mathrm{L}{ }^{-1}$ below $45 \mathrm{~cm}$. Finally, the aqueous hydrogen sulfide $\left(\mathrm{HS}^{-}\right)$concentration was below the detection limit in all porewaters analyzed.

3.3. Fe and Ni Concentrations in the Solid Fraction. Because the mangrove stand investigated is located downstream of formerly mined $\mathrm{Ni}$-rich lateritic regoliths, the $\mathrm{Fe}$ and $\mathrm{Ni}$ concentrations in the sediments are elevated (Figure $2 c, d$ ) compared to concentrations reported for mangroves worldwide. ${ }^{21,52} \mathrm{Fe}$ concentration in the dry sediment samples ranges from 8 to $30 \mathrm{wt} \% \mathrm{Fe}$ (Figure 2c; Table SI-2). This concentration is $\sim 13$ wt $\%$ Fe from 5 to $15 \mathrm{~cm}$ and it reaches its maximum value $(29 \mathrm{wt} \% \mathrm{Fe})$ at $20 \mathrm{~cm}$. Finally, it ranges from 11 to 17 wt \% Fe from 25 to $40 \mathrm{~cm}$, and it reaches its lowest value $(\sim 9$ wt $\% \mathrm{Fe})$ below $50 \mathrm{~cm}$. Ni concentration is $\sim 2900 \mathrm{mg} \cdot \mathrm{kg}^{-1} \mathrm{Ni}$ from 5 to $20 \mathrm{~cm}$ (Figure 2d; Table SI-2). It decreases to a mean value of $\sim 1100 \mathrm{mg} \cdot \mathrm{kg}^{-1} \mathrm{Ni}$ from 20 to 40 $\mathrm{cm}$, then increases to its maximum value of $\sim 6000 \mathrm{mg} \cdot \mathrm{kg}^{-1} \mathrm{Ni}$ at $50 \mathrm{~cm}$ before dropping to $\sim 4500 \mathrm{mg} \cdot \mathrm{kg}^{-1} \mathrm{Ni}$ from 60 to 70 $\mathrm{cm}$.

3.4. Distribution and Quantitative Speciation of Fe in the Solid Fraction. Fe K-edge EXAFS spectra of the samples down to $40 \mathrm{~cm}$ depth (Figure 3 ) compare well with those of

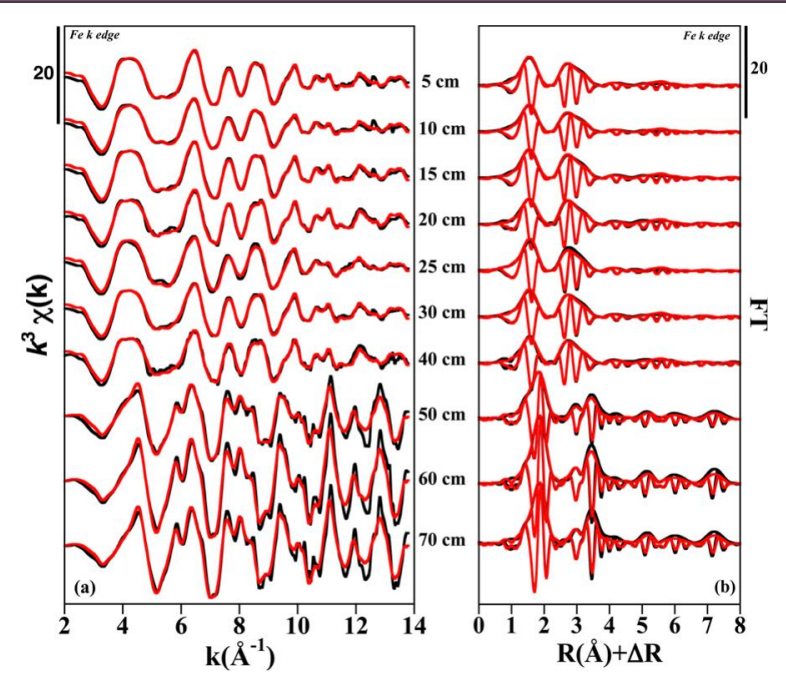

Figure 3. Vertical changes of Fe K-edge (a) $k^{3}$-weighted EXAFS spectra and (b) their corresponding Fourier-transforms as a function of depth in the studied mangrove sediments. The black and red lines correspond to the experimental data and the LC-LS fits, respectively. See Figure $2 c$ and Table SI-6 for quantitative results. Depths below ground surface are noted numerically.

Fe-bearing phyllosilicates and Fe-bearing goethite (Figure SI3). Accordingly, the Fe K-edge XANES of these samples show features characteristic of the Fe-bearing phyllosilicate and $\mathrm{Fe}$ bearing goethite XANES spectra (i.e., the shape of the white line at $7130 \mathrm{eV}$ and feature around $7150 \mathrm{eV}$; Figure SI-5a). In contrast, Fe K-edge EXAFS and XANES spectra of the deeper horizons of the sediments (from 50 to $70 \mathrm{~cm}$ ) (Figures 3 and
SI-5a) compare well with the Fe-XAS spectra of pyrite (Figures SI-3, SI-5a). These observations suggest that Fe speciation changes from $\mathrm{Fe}$-bearing phyllosilicates and goethite above 40 $\mathrm{cm}$ depth to pyrite below that depth, in agreement with PCATT (Tables SI-3, SI-4) and XRD results (Figure SI-2).

Thus, the best LC-LS fits of the Fe K-edge EXAFS spectra were obtained with goethite, Fe-Illite, and pyrite model compound spectra as fitting components (Figure SI-3). This result is in agreement with our previous Fe-EXAFS study of mangrove sediments at the Vavouto Bay in the Northern Province of New Caledonia. ${ }^{22}$ Accordingly, Illite has to be considered here as a proxy for dioctahedral 2:1 phyllosilicates, such as Fe-smectite that was directly identified in the Vavouto sediments. $^{22}$ In addition to these three components, ferrihydrite $\left(\mathrm{Fe}_{5} \mathrm{O}_{3}(\mathrm{OH})_{9}\right)$ and schwertmannite $\left(\mathrm{Fe}_{8} \mathrm{O}_{8}(\mathrm{OH})_{6} \mathrm{SO}_{4}\right)$ were also tested as components of the LC-LS fits. Indeed, the $\mathrm{TT}$ procedure performed on Fe K-edge EXAFS data retained these two mineral species as possible components (Table SI-4). Moreover, ferrihydrite has been previously reported as a major Fe-bearing phase in mangrove sediments ${ }^{21,22}$ and schwertmannite is known to occur as a major Fe-bearing species in acidic sulfate soils. ${ }^{31,53}$ Adding ferrihydrite as a fitting component improved the goodness of fit for the samples collected above $20 \mathrm{~cm}$ depth by about 30\% (Table SI-5), whereas adding schwertmannite improved the fit quality of the Fe K-edge EXAFS spectra of samples collected in the oxic/ suboxic horizon at 25 and $30 \mathrm{~cm}$ by 30 and $38 \%$, respectively (Table SI-5). Distinguishing between ferrihydrite and schwertmannite as minor components of the Fe K-edge XAS data is not straightforward because of the similarities in their EXAFS and XANES spectral features. However, the dramatic evolution of the color of the mangrove sediment (Figure 2a) and the strong increase of the dissolved iron and sulfates concentrations measured in the pore-waters (Figure 1b,c) above and below 25 $\mathrm{cm}$ depth support the hypothesis of a preferential precipitation of ferrihydrite above $20 \mathrm{~cm}$ and a preferential precipitation of schwertmannite between 25 and $40 \mathrm{~cm} .{ }^{54,55}$ In contrast, adding other $\mathrm{Fe}$-oxyhydroxides retained as reasonable components during the TT procedure (i.e., lepidocrocite or maghemite; Table SI-4), did not improve the fit quality (Table SI-5). Finally, despite the large TOC of the mangrove sediments investigated, addition of $\mathrm{Fe}$ (III)-humate as a possible model compound did not improve the fit quality of the Fe-EXAFS spectra of the mangrove sediment.

LC-LS fitting of the Fe K-edge EXAFS spectra show that $\mathrm{Fe}$ in the sediments collected between 5 and $40 \mathrm{~cm}$ is mainly hosted by $\mathrm{Fe}$-oxyhydroxides ( $\sim 74 \%$ of total $\mathrm{Fe})$ with goethite representing between 32 and $65 \%$, ferrihydrite accounting for 14-36\% above $20 \mathrm{~cm}$ depth, and schwertmannite accounting for $10-33 \%$ between 25 and $40 \mathrm{~cm}$ depth (Figure 2c; Table SI6). Phyllosilicates $(17-39 \%$ of the total $\mathrm{Fe}$ ) also represent a significant fraction of $\mathrm{Fe}$ speciation in these samples. In contrast, pyrite is the main Fe-bearing species between depths of 50 and $70 \mathrm{~cm}(57-88 \%$ of total $\mathrm{Fe})$ as observed by SEM in Figure 4 . The remaining fraction of $\mathrm{Fe}$ in these bottom samples is incorporated in Fe-bearing phyllosilicates $(12-28 \%$ of total Fe; Figure 2c; Table SI-6).

3.5. Distribution and Quantitative Speciation of $\mathrm{Ni}$ in the Solid Fraction. As for the Fe K-edge EXAFS spectra, the Ni K-edge EXAFS spectra and their FTs show some changes with depth, indicating a vertical change in $\mathrm{Ni}$ speciation (Figure 5 ). Indeed, the FTs of the samples above $25 \mathrm{~cm}$ exhibit firstand second-neighbor peaks at $\sim 1.62$ and $\sim 2.78 \AA$, respectively 

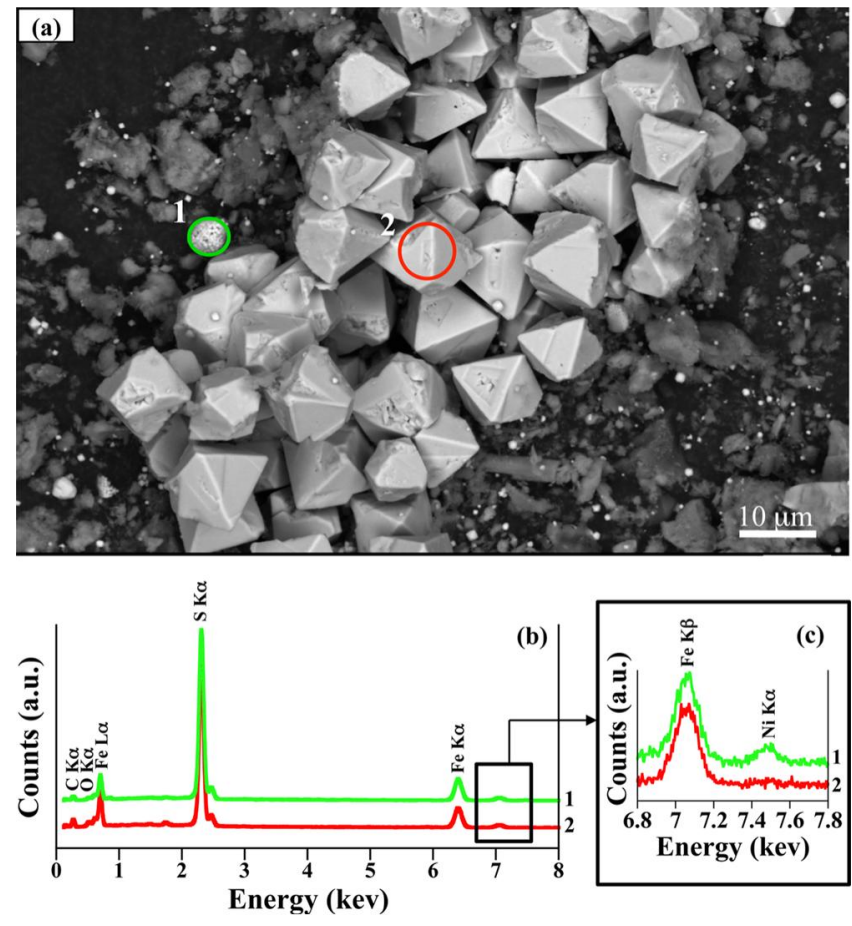

Figure 4. SEM image and SEM-EDS analyses of pyrite grains from the sample collected at $70 \mathrm{~cm}$ depth. The SEM image in (a) shows two types of pyrite: a first one constituted of cuboctahedral pyrites of approximately $10 \mu \mathrm{m}$ (red) and a second one constituted of spherulitic pyrites of a few hundreds of nanometers (green). The SEM-EDS spectra corresponding to these two types of pyrite are displayed in $(\mathrm{b}, \mathrm{c})$.

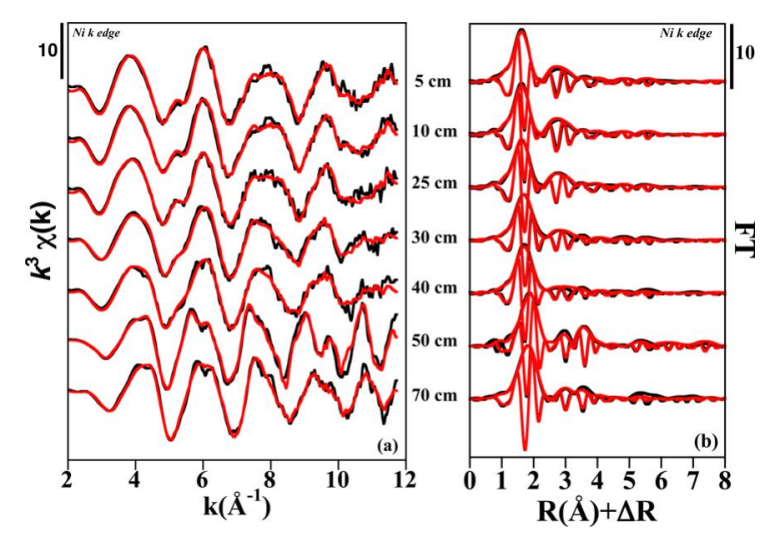

Figure 5. Vertical changes of the Ni K-edge (a) $k^{3}$-weighted EXAFS spectra and (b) their corresponding Fourier-transforms as a function of depth in the studied mangrove sediments. The black and red lines correspond to the experimental data and the LC-LS fits, respectively. See Figure $2 \mathrm{~d}$ and Table SI-9 for quantitative results. Depths below ground surface are noted numerically.

(uncorrected for phase shift; Figure $5 \mathrm{~b}$ ), that are characteristic of the $\mathrm{Ni}-\mathrm{O}$ and $\mathrm{Ni}-$ cation distances found in Ni-bearing $\mathrm{Fe}$ oxides and Ni-bearing phyllosilicates ${ }^{36,56,57}$ (Figure SI-4). In contrast, the FTs of the samples below $50 \mathrm{~cm}$ exhibit first-, second-, and third-neighbor peaks at $\sim 1.83, \sim 2.98$, and $\sim 3.56$ $\AA$, respectively, (uncorrected for phase shift; Figure $5 \mathrm{~b}$ ), that are characteristic of the distances found in Ni-bearing iron sulfides $^{23}$ (Figure SI-4). This change with depth from Nibearing Fe-oxides and Ni-bearing phyllosilicates to Ni-bearing iron sulfides is also observed for Ni K-edge XANES spectra
(Figure SI-5b). These observations suggest that $\mathrm{Ni}$ speciation changes from Ni-bearing phyllosilicates and Ni-bearing Feoxides above $50 \mathrm{~cm}$ to Ni-bearing Fe-sulfides below that depth. SEM-EDXS analyses of the samples collected in the bottom horizons (below $50 \mathrm{~cm}$ ) confirm the presence of $\mathrm{Ni}$ in pyrite and indicate the occurrence of two pools of Ni-bearing pyrite more or less enriched in $\mathrm{Ni}$ (Figure 4; more information is detailed in Section 7 of the SI, Figure SI-6).

In a previous study on the mangrove sediments at the Vavouto Bay (Northern Province, New Caledonia), Nigoethite, Ni-bearing talc and montmorillonite, Ni-pyrite, and $\mathrm{Ni}$-rich pyrite have been shown to be the major $\mathrm{Ni}$ species beneath the Avicennia stand. ${ }^{23}$ The LC-LS fits of the Ni K-edge EXAFS spectra of the sediment samples studied were also initially performed with these five $\mathrm{Ni}$ species (Figure SI-4). Following this procedure, the Ni-pyrite and Ni-rich pyrite were found to be good model compounds for the LC-LS fits of the Ni K-edge EXAFS spectra from most of the reduced samples of the present study. However, the Ni-sorbed pyrite was found to be the best model compound for the samples collected at 30 $\mathrm{cm}$ (Table SI-7; Figure SI-7) and $40 \mathrm{~cm}$ depth (Table SI-7; Figure SI-8). Moreover, addition of the Ni EXAFS spectrum of the Ni-sorbed pyrite model compound to the LC-LS fits from the samples collected in the deepest horizons of the sediments studied (i.e., between 50 and $70 \mathrm{~cm}$ ) also improved significantly the goodness of fit (mean improvement $\sim 45 \%$; Table SI-8). As a consequence, in order to compare the whole set of Ni-EXAFS spectra on a same basis, the Ni K-edge EXAFS spectrum of $\mathrm{Ni}$ sorbed pyrite was systematically included as a sixth model compound in the LC-LS fits from all sediment samples studied.

The results of this LC-LS fitting procedure show that the sediments collected above $25 \mathrm{~cm}$ are characterized by a major incorporation of $\mathrm{Ni}$ in phyllosilicates, such as montmorillonite and talc (around $60 \%$ of total $\mathrm{Ni}$ ) and a significant incorporation in goethite (around $40 \%$ of total Ni; Figure 2d; Table SI-9). These two Ni mineral hosts also occur in the samples collected between 30 and $40 \mathrm{~cm}$, with $\mathrm{Ni}$ montmorillonite and Ni-goethite representing about $35 \%$ and $21 \%$ of total $\mathrm{Ni}$, respectively. In addition, these samples also hold a significant fraction of Ni-sorbed pyrite (i.e., between $35 \%$ and $40 \%$ of total Ni; Figure 2d). Finally, the sediments collected between 50 and $70 \mathrm{~cm}$ are characterized by a major fraction of $\mathrm{Ni}$ associated with pyrite (both as sorbed and incorporated Ni; Table SI-9).

\section{DISCUSSION}

4.1. Consequences of Mangrove Isolation on the Physicochemical Characteristics of the Sediments. The sediments studied were sampled beneath an Avicennia stand, which usually develops at intermediate elevation along the tidal zone and exhibit pore-water salinities usually higher than that of seawater because of evapo-transpiration processes. ${ }^{7,58,59}$ However, the salinity measured within the top $25 \mathrm{~cm}$ of the mangrove sediment studied here is intermediate between those of seawater ${ }^{35}$ and freshwater $(<0.5$; Figure 1a). This low salinity compared to that of sediments beneath a conventional Avicennia stand suggests that the upper horizons of the sediments investigated are no longer recharged by seawater but only by rainwater. This process is thought to occur because of the isolation from the sea after a road construction. In Guyana mangrove, Lamb et al. ${ }^{60}$ suggested that the freshwater inflows can dissolve the salts precipitated in the sediment horizons during dry periods, providing high salinity of their 
pore-waters. Thus, in the present study we propose that the salinity decrease observed within the first $25 \mathrm{~cm}$ depth of the sediments results from such a repeated alternation of saturated/ unsaturated conditions that lead to alternative salts dissolution/ precipitation events. This phenomenon is not observed at depth (Figure 1a) either because the salts dissolved near the surface are transported downward with percolating rainwater ${ }^{61}$ or because the bottom horizon of these sediments is still under tidal influence through groundwater flow within permeable horizons. $^{62}$ Further research is needed to define the exact mechanism that provides the high salinities of pore-waters at depth.

Redox potential measurements were widely described in the mangrove sediments as biogeochemical tracers of redox scale $7,58,59$ and were thus chosen to compare redox state of mangrove sediments isolated from the sea with that of mangrove sediments that are still connected with the sea. The sediments beneath Avicennia stands in New Caledonia exhibit usually a gradually decrease from suboxic conditions (lack measurable oxygen or sulfide but contain dissolved iron or manganese, no reduction of sulfate ${ }^{22,59}$ ) to anoxic conditions (sulfate reduction ${ }^{22,59}$ ) along the first $20 \mathrm{~cm}$ depth (from 300 to $\left.0 \mathrm{mV}^{7,22,58,59}\right)$. However, the high redox potential values (300-490 mV; Figure 2b) measured within the top $40 \mathrm{~cm}$ of the mangrove sediment studied here could translate the presence of oxidizing conditions. ${ }^{59,63}$ This values range was previously described to translate the presence of measurable dissolved oxygen, however this statement require further research in order to better understand the dissolved oxygen cycling in the mangrove sediments and will be cover in a separate paper. These observations corroborate the results of salinity distribution that suggest a repeated alternation of rainwater inputs followed by unsaturated conditions. Such inputs of oxic rainwater in the surface horizons of the mangrove sediments, together with the lack of replenishment by seawater after evaporation during dry periods, could thus explain their high redox potential values (Figure $2 b$ ). In such a context the very low $\mathrm{pH}$ values (i.e., between 2.9 and 5.2; Figure 2b) compared with those usually measured in sediments beneath Avicennia stands in New Caledonia (close to $6 ;^{7,58,59}$ ) might be due to oxidative dissolution of Fe-sulfides previously formed under reducing conditions. ${ }^{21,22,64}$

4.2. Consequences of the Reoxidation on Fe Cycling in the Mangrove Sediments. Above $50 \mathrm{~cm}$, Fe K-edge XAS data indicate that $\mathrm{Fe}$ is hosted by goethite, ferrihydrite, schwertmannite, and illite, as a proxy for smectite (Figure 2c; Table SI-6). The occurrence of Fe-bearing smectite has already been demonstrated in mangrove sediments of New Caledonia, and it is considered to result either from in situ formation ${ }^{22}$ or to have been inherited from past marine transgressions. ${ }^{65}$ Goethite is the most abundant $\mathrm{Fe}$ (III)-species in lateritic regoliths developed upon ultramafic rocks in New Caledonia $^{36,66}$ and it is thought to have been directly inherited from the erosion of these lateritic regoliths. ${ }^{22,23}$ In contrast, ferrihydrite and schwertmannite have not been reported in the lateritic regoliths of New Caledonia and these two mineral species are considered to result from in situ precipitation in the mangrove sediments studied. The precipitation of ferrihydrite along the first $20 \mathrm{~cm}$ depth is expected to result from the complex and cyclic interplay between the reduction of $\mathrm{Fe}$ (III)oxyhydroxides that releases dissolved $\mathrm{Fe}^{2+}$ in the pore-waters and the partial reoxidation of this dissolved $\mathrm{Fe}^{2+}$ in a sulfatelimited environment, as usually observed in conventional sediments beneath Avicennia stands. ${ }^{21,22}$ The precipitation of schwertmannite between 25 and $40 \mathrm{~cm}$ is proposed to result from similar processes, although dissolved $\mathrm{Fe}^{2+}$ is not provided by the reductive dissolution of $\mathrm{Fe}$ (III)-oxyhydroxides but rather by the oxidative dissolution of pyrite, ${ }^{67,68}$ which may be considered to take place in three major steps: (1) oxidation of sulfur (eq 1); (2) oxidation of ferrous iron (eq 2); and (3) hydrolysis and precipitation of ferric complexes and schwertmannite (eq 4)

$$
\begin{aligned}
& 8 \mathrm{FeS}_{2}+28 \mathrm{O}_{2}+8 \mathrm{H}_{2} \mathrm{O} \rightarrow 8 \mathrm{Fe}^{2+}+16 \mathrm{SO}_{4}{ }^{2-}+16 \mathrm{H}^{+} \\
& 8 \mathrm{Fe}^{2+}+2 \mathrm{O}_{2}+8 \mathrm{H}^{+} \rightarrow 8 \mathrm{Fe}^{3+}+4 \mathrm{SO}_{4}{ }^{2-}+16 \mathrm{H}^{+} \\
& \mathrm{FeS}_{2}+14 \mathrm{Fe}^{3+}+8 \mathrm{H}_{2} \mathrm{O} \rightarrow 15 \mathrm{Fe}^{2+}+2 \mathrm{SO}_{4}{ }^{2-}+16 \mathrm{H}^{+} \\
& 8 \mathrm{Fe}^{3+}+\mathrm{SO}_{4}{ }^{2-}+14 \mathrm{H}_{2} \mathrm{O} \rightarrow \mathrm{Fe}_{8} \mathrm{O}_{8}(\mathrm{OH})_{6}\left(\mathrm{SO}_{4}\right)+22 \mathrm{H}^{+}
\end{aligned}
$$

This hypothesis is supported by the high Eh values measured in the horizons between 25 and $40 \mathrm{~cm}$ (Figure 2b), combined with the high $\mathrm{SO}_{4}{ }^{2-} / \mathrm{Cl}^{-}$molar ratio and total $\mathrm{Fe}$ concentration measured in the corresponding pore-waters (eqs 1-3; Figure $1 \mathrm{~b}, \mathrm{c})$. The traces of dissolved $\mathrm{Fe}^{3+}$ revealed in the pore-waters collected at 30 and $40 \mathrm{~cm}$ depths (Figure 1c) indicate that the local conditions are favorable to the oxidation of dissolved $\mathrm{Fe}^{2+}$ to $\mathrm{Fe}^{3+}$ (eq 2). Moreover, the very low $\mathrm{pH}$ values measured in these horizons (i.e., between 3 and 4; Figure 2b) strongly support the in situ precipitation of secondary $\mathrm{Fe}$ (III) oxyhydroxy-sulfates (eq 4). The net reaction of complete oxidation of pyrite, hydrolysis of $\mathrm{Fe}^{3+}$ and precipitation of schwertmannite (sum of reactions 1, 2, and 4, i.e., eq 5) produces $30 \mathrm{~mol}$ of $\mathrm{H}^{+}$per $8 \mathrm{~mol}$ of pyrite

$$
\begin{aligned}
& 8 \mathrm{FeS}_{2}+30 \mathrm{O}_{2}+18 \mathrm{H}_{2} \mathrm{O} \\
& \quad \rightarrow \mathrm{Fe}_{8} \mathrm{O}_{8}(\mathrm{OH})_{6}\left(\mathrm{SO}_{4}\right)+30 \mathrm{H}^{+}+15 \mathrm{SO}_{4}{ }^{2-}
\end{aligned}
$$

In addition, in such acidic to near-neutral $\mathrm{pH}$ sulfate-rich waters, precipitation of schwertmannite is favored compared to other secondary $\mathrm{Fe}$ (III)-oxyhydroxy-sulfates and $\mathrm{Fe}$ (III)-oxyhydroxides. ${ }^{69,70}$

Below $50 \mathrm{~cm}$, the situation is very different because the anoxic conditions (Figure $2 \mathrm{~b}$; Table SI-1) favor the pyritization of the goethite inherited from erosion of the lateritic regoliths, as already demonstrated in other mangrove sediments from New Caledonia. ${ }^{22,23}$ These anoxic conditions explain the major occurrence of $\mathrm{Fe}$ in the form of pyrite (i.e., $55-87 \%$ of total $\mathrm{Fe}$; Figure 2c), especially in the form of cuboctahedral pyrites with diameters larger than $10 \mathrm{~mm}$ (Figure 4). These conditions also explain the absence of goethite and of secondary $\mathrm{Fe}(\mathrm{III})$ oxyhydroxides and/or $\mathrm{Fe}$ (III)-oxyhydroxy-sulfates (Figure $2 \mathrm{c}$; Table SI-6). Results obtained below $50 \mathrm{~cm}$ indicate that the anoxic conditions usually observed at shallow depths in mangrove sediments beneath Avicennia stands, which are favorable to pyrite formation and preservation, ${ }^{7,22}$ are currently observed in the mangrove sediments studied. In this context, partial oxidation of pyrite is unlikely, and the high $\mathrm{SO}_{4}{ }^{2-}$ and dissolved $\mathrm{Fe}^{2+}$ concentrations measured in the pore-waters of these bottoms horizons (Figure $1 \mathrm{~b}, \mathrm{c}$ ) are likely explained by downward diffusion of these solutes toward the bottom layers of the sediment. 


\subsection{Consequences of the Reoxidation on Ni Cycling} in the Mangrove Sediments. Above $25 \mathrm{~cm}$, the reoxidation of the mangrove sediments seems not to have had any influence on $\mathrm{Ni}$ speciation in solids. Indeed, $\mathrm{Ni}$ K-edge XAS data indicate that $\mathrm{Ni}$ is associated with goethite, talc, and montmorillonite (Figure 2d; Table SI-9). Our observations corroborate the results of Marchand et al., ${ }^{7}$ which showed from sequential chemical extractions that $\mathrm{Ni}$ in the upper part of sediments (from surface to $20-30 \mathrm{~cm}$ ) beneath Avicennia stand from the Dumbea Bay that is still connected with the sea is only bounded with oxides and residual phase. Moreover, this distribution of $\mathrm{Ni}$ species is similar to that reported for the uppermost horizon of the mangrove sediments at the Vavouto Bay (Northern Province, New Caledonia ${ }^{23}$ ). Ni-bearing goethite $^{36,66}$ and Ni-bearing talc $\mathrm{c}^{36,71}$ are inherited from erosion of the lateritic regolith. ${ }^{23}$ The origin of Ni-bearing smectite in the upper horizons of the mangrove sediments is more difficult to establish. It could form in situ as Fe-rich smectite ${ }^{23}$ or could be eroded from lateritic regoliths. Indeed, Ni-smectite is known to form $\mathrm{Ni}$-ores referred as clay silicate deposits in poorly drained lateritic regoliths developed upon ultramafic rocks in Australia, Ural, Burundi, and Brazil. ${ }^{72}$ It is also known to occur in the Tiebaghi regolith in New Caledonia, further north than the area studied here. ${ }^{72}$

Below $25 \mathrm{~cm}$ depth, Ni-sorbed pyrite occurs in addition to Ni-bearing goethite and phyllosilicates (Figure 2d; Tables SI-7, SI-9). Sorption of $\mathrm{Ni}^{2+}$ onto pyrite can be explained by the affinity of this divalent cation for the surface of Fe-sulfides. ${ }^{73,74}$ Although previous laboratory studies indicate that $\mathrm{Ni}^{2+}$ could also sorb onto the surface of goethite and phyllosilicates, ${ }^{73-77}$ our Ni K-edge XAS data indicate that it is not a dominant process in these mangrove sediments. This result is in agreement with the preferential sorption of several divalent cations onto $\mathrm{Fe}$-sulfides rather than onto $\mathrm{Fe}$ (III)-hydroxides under acidic $\mathrm{pH}^{73}$ that is, $\mathrm{pH} \sim 3$ in the sediment horizons considered here (Figure 2b; Tables SI-1). Such a high affinity of $\mathrm{Ni}^{2+}$ for pyrite could explain why $\mathrm{Ni}$-sorbed pyrite could be detected by $\mathrm{Ni}$ K-edge EXAFS analysis in the mangrove sediment samples at depths of 30 and $40 \mathrm{~cm}$ (Figure 2d; Tables SI-7, SI-9), whereas pyrite was found to be below the detection limit of Fe K-edge XAS ( $<10 \%$ of total Fe) in the same samples (Figure 2c; Table SI-6).

The presence of $\mathrm{Ni}$-sorbed pyrite is interpreted as resulting from the release of aqueous $\mathrm{Ni}(\mathrm{II})$, due to oxidative dissolution of pyrite at the redox boundary $(25-40 \mathrm{~cm}$ depth) and subsequent readsorption of $\mathrm{Ni}$ (II) onto remaining pyrite, at the same depth and downward in the sediment profile (below 40 $\mathrm{cm}$ depth). Accordingly, $\mathrm{Ni}$-sorbed pyrite was previously identified close to the shore, under a Rhizophora stand in the Vavouto mangrove sediments, where it was interpreted as resulting from the oxidative dissolution of $\mathrm{Ni}$-pyrite, due to tide cycles. $^{22,23}$ Moreover, if pyrite would have formed in the presence of the high dissolved $\mathrm{Ni}$ that were measured in the pore-waters collected around $30 \mathrm{~cm}$ (up to $790 \mu \mathrm{mol} \mathrm{L} \mathrm{L}^{-1}$, Figure 1d), Ni-incorporated pyrite should have been favored over Ni-sorbed pyrite. Hence, Ni-sorbed pyrite in the samples at 30 and $40 \mathrm{~cm}$ depths result from sorption of dissolved $\mathrm{Ni}$ on remnants of pyrite rather than from sorption of dissolved $\mathrm{Ni}$ on newly formed pyrite. The horizons between 25 and $50 \mathrm{~cm}$ depth are thus interpreted as former pyritized horizons that are reoxidized as a consequence of the isolation of the mangrove stand from the sea. At this reoxidation front, the low $\mathrm{pH}$ (Figure $2 \mathrm{~b}$ ), high $\mathrm{SO}_{4}{ }^{2-} / \mathrm{Cl}^{-}$ratio (Figure $\mathrm{lb}$ ) and dissolved
$\mathrm{Fe}^{2+}$ concentration (Figure 1c), as well as the occurrence of schwertmannite (Figure 2c), likely result from oxidative dissolution of Fe-sulfides. The large amounts of dissolved $\mathrm{Ni}$ are thus considered to originate from the oxidative dissolution of former Ni-bearing pyrites.

In the sediment samples below $50 \mathrm{~cm}$ depth, Ni K-edge EXAFS results indicate that about half of the total $\mathrm{Ni}$ is incorporated in the pyrite structure, in addition to sorbing on pyrite surfaces (Table SI-9). Incorporation of $\mathrm{Ni}$ in the pyrite structure is not surprising, as pyrite is known to form solid solution with transition metal ions and acts as a sink for these elements in anoxic sediments. ${ }^{23,24,78}$ In the bottom horizons of the sediment studied here, $\mathrm{Ni}$ content is significantly higher than in the overlying reoxidation zone (Figure $2 \mathrm{~d}$ ) and it is also significantly higher than that measured in the fraction of the mangrove sediments from the Dumbea Bay that is still connected with the sea. ${ }^{7}$ This comparison suggests a $\mathrm{Ni}$ enrichment of the deep horizons of the mangrove sediments that could result from the downward percolation of dissolved $\mathrm{Ni}$ from the overlying reoxidation front. This hypothesis is in agreement with the very large amount of dissolved $\mathrm{Ni}$ measured in the pore-waters at this overlying reoxidation front (Figure 1d). These observations corroborate the results of Marchand et al., ${ }^{61}$ which showed in the Guyana mangroves that dissolved organic matter near the surface are transported downward with percolating rainwater. The larger body of $\mathrm{Fe}^{3+}$ in the dissolved phase suggesting the formation of colloidal Fe-oxyhydroxide and/or organic-Fe colloids, which could complex with this dissolved organic matter (Figure $1 c^{49,50}$ ) and act a carrier facilitating $\mathrm{Ni}$ transport. The mechanisms responsible for this accumulation at depth requires additional research to be fully understood, however such a percolation of dissolved $\mathrm{Ni}$ from the reoxidation front to the deepest horizons would explain the significant fraction of Ni-sorbed pyrite in these horizons where pyrite is considered to be stable because of the anoxic conditions (Figure 2).

4.4. Environmental Implications. The concentration of dissolved $\mathrm{Ni}$ measured in pore-waters just above and at the reoxidation front (Figure 1d) is larger than that previously measured in pore-waters of other mangrove sediments from New Caledonia. ${ }^{7,23}$ More importantly, it is up to 100 times higher than that measured in the same mangrove sediments that are still under the influence of tidal reinundation. ${ }^{7}$ The reoxidation of the mangrove sediments studied here in response to their isolation from the sea leads to dramatic release of dissolved $\mathrm{Ni}$ in pore-waters of the oxygenated horizons. As suggested by XAS data, this release of dissolved $\mathrm{Ni}$ is likely due to the oxidative dissolution of Ni-bearing pyrite that formed when the same sediments were anoxic/suboxic. Such a mechanism is similar to that already proposed for the mobilization of metals in relation to oxidation and acidification during acid sulfate soil formation in Australia. ${ }^{32,33}$

At the reoxidation front, only a small fraction of dissolved $\mathrm{Ni}$ released by the oxidative dissolution of $\mathrm{Ni}$-bearing pyrite is sorbed on surfaces of residual pyrite. This dissolution of $\mathrm{Ni}$ bearing pyrite results in a significant leaching of dissolved $\mathrm{Ni}$ toward the bottom anoxic/suboxic horizons where it accumulates through a combination of coprecipitation with pyrite and sorption on pyrite surfaces. These reactions lead to an accumulation of $\mathrm{Ni}$ at depth in the sedimentary column, whereas the concentration of dissolved $\mathrm{Ni}$ is significantly lower than at the overlying reoxidation front (i.e., $<100 \mu \mathrm{mol} \mathrm{L}{ }^{-1}$ compared to $790 \mu \mathrm{mol} \mathrm{L}{ }^{-1}$; Figure 1d). This latter point 
emphasizes the importance of Fe-sulfides in mitigating the dispersion of $\mathrm{Ni}$ upon reoxidation of former pyritized mangrove sediments, provided that the anoxic/suboxic conditions are maintained in the deeper horizons of the sediment. In addition, the occurrence of $\mathrm{Ni}$-sorbed pyrite at depth raises the question of the possible effect of a reconnection of the mangrove sediments to tidal reinundation that would yield an increased ionic strength of the pore-waters, and then, a possible desorption of $\mathrm{Ni}$ from Fe-sulfides in these horizons due to competitive effects of other ions. 79,80

\section{CONCLUSION}

We surveyed $\mathrm{Fe}$ and $\mathrm{Ni}$ behavior in mangrove sediments subjected to isolation from the sea in response to increasing anthropogenic pressure, resulting in strong oxidation of sediment. A previous study shown that Ni-incorporation in pyrite formed under anoxic/suboxic conditions of mangrove sediments beneath Avicennia stand can efficiently trap $\mathrm{Ni}$, protecting marine ecosystem against $\mathrm{Ni}$ dispersion. ${ }^{22}$ In this study, the quantitative distribution and speciation of $\mathrm{Fe}$ and $\mathrm{Ni}$ species in solid fraction was compared with their concentration in pore-water as a function of redox gradients in order to evaluate impact of oxidation of Ni-rich mangrove sediments beneath Avicennia stand on the Ni remobilization. The image that our results arises in this study is one in which (i) unusual suboxic/oxic conditions favor the oxidative dissolution of $\mathrm{Ni}$ pyrite and (ii) leads to dramatic release of dissolved $\mathrm{Ni}$ in porewaters. Considering the known affinity for the surface or structure of Fe-sulfides, ${ }^{28,29,67,74}$ our results suggest that (iii) $\mathrm{Ni}$ remobilization is mitigated by interaction with pyrite preserved into the underlying anoxic horizons as long as the anoxic conditions are preserved at depth. These conclusions can likely be extended to other divalent metals like $\mathrm{Co}, \mathrm{Cu}$, and $\mathrm{Zn}$ and to a large set of mangrove sediments worldwide. Taking into account tidal pumping on the export of elements from mangrove sediments toward adjacent ecosystems, ${ }^{81,82}$ porewater seepage enriched in dissolved metals after such oxidation may have severe effects on coastal communities. This study emphasizes the need for further long-term monitoring of mangrove sediments after completed or ongoing reoxidation in order to evaluate the consequences of this anthropogenic forcing on the mobility of metals at the land-sea interface.

1) Site studied; 2) Analytical methods; 3) Chemistry and mineralogy of the mangrove sediments; 4) Model compounds for X-ray absorption spectroscopy analysis; 5) Fe and Ni K-edge XANES data: evidence for a vertical change of $\mathrm{Fe}$ and $\mathrm{Ni}$ redox states along the studied mangrove sediments; 6) Fe K-edge EXAFS data analysis by principal component analysis (PCA) and target transform analysis (TT); 7) Ni K-edge EXAFS signature of Ni incorporated in pyrite; 8) Test and results of linear combination least-squares (LC-LS) fitting of $\mathrm{Fe}$ and $\mathrm{Ni}$ K-edge EXAFS data (PDF)

\section{AUTHOR INFORMATION}

\section{Corresponding Author}

*E-mail: noel@slac.stanford.edu.

ORCID

Vincent Noël: 0000-0002-5387-8664

Notes

The authors declare no competing financial interest.

\section{ACKNOWLEDGMENTS}

This study was funded by Koniambo Nickel SAS (KNS) within the framework of a project aimed at understanding the biogeochemical behavior of metals in the sediments of mangroves from New Caledonia. Laure Cordier and Mickael Tharaud (IPGP/Paris Diderot) are acknowledged for ICP-AES and ICP-MS measurements, respectively. The authors wish to thank Imene Esteve for her help during SEM observations and SEM-EDXS analyses and Ludovic Delbes for handling the Xray diffraction equipment under anoxic conditions at IMPMC (Paris, France). The technical staffs at ESRF (Grenoble, France), SOLEIL (Saclay, France), ELETTRA (Trieste, Italy), and SSRL (Menlo Park, California, U.S.A.) are greatly acknowledged for their help during XAS measurements. SSRL and SLAC are supported by the U.S. Department of Energy, Office of Science, Office of Basic Energy Sciences under Contract No. DE-AC02-76SF00515, the DOE Office of Biological and Environmental Research, and by the National Institutes of Health, National Institute of General Medical Sciences (including P41GM103393). Partial support was provided by the U.S. Department of Energy, Office of Biological and Environmental Research (BER), Subsurface Biogeochemical Research (SBR) program under subcontract DE-AC02-76SF00515.

\section{REFERENCES}

(1) Valiela, I.; Bowen, J. L.; York, J. K. Mangrove forests: one of the world's threatened major tropical environments. BioScience 2001, 51, 807-815.

(2) Duke, N. C.; Meynecke, J.-O.; Dittmann, S.; Ellison, A. M.; Anger, K.; Berger, U.; Cannicci, S.; Diele, K.; Ewel, K. C.; Field, C. D.; Koedam, N.; Lee, S. Y.; Marchand, C.; Nordhaus, I.; Smith, T. J., III; Dahdouh-Guebas, F. A world without mangroves? Science 2007, 317, $41-42$.

(3) Tam, N. F. Y.; Wong, Y. S. Spatial variation of heavy metals in surface sediments of Hong Kong mangrove swamps. Environ. Pollut. 2000, 110, 195-205.

(4) Qiu, Y. W.; Yu, K. F.; Zhang, G.; Wang, W. X. Accumulation and partitioning of seven trace metals in mangroves and sediment cores from three estuarine wetlands of Hainan Island, China. J. Hazard. Mater. 2011, 190, 631-638.

(5) Giblin, A. E.; Bourg, A.; Valiela, I.; Teal, J. M. Uptake and Losses of Heavy Metals in Sewage Sludge by a New England Salt Marsh. Am. J. Bot. 1980, 67, 1059-1068.

(6) Silva, C. A. R; Lacerda, L. D.; Rezende, C. E. Metals Reservoir in a Red Mangrove Forest. Biotropica 1990, 22, 339-345.

(7) Marchand, C.; Fernandez, J.; Moreton, B.; Landi, L.; Lalliervergès, E.; Baltzer, F. The partitioning of transitional metals ( $\mathrm{Fe}, \mathrm{Mn}$, $\mathrm{Ni}, \mathrm{Cr}$ ) in mangrove sediments downstream of a ferralitized ultramafic watershed (New Caledonia). Chem. Geol. 2012, 300-301, 70-80.

(8) Davari, A.; Danehkar, A.; Khorasani, N.; Poorbagher, H. Heavy metal contamination of sediments in mangrove forests of the Persian Gulf. Food, Agriculture and Environment (JFAE) 2010, 8 (3-4), 12801284.

(9) Bayen, S. Occurrence, bioavailability and toxic effects of trace metals and organic contaminants in mangrove ecosystems: A review. Environ. Int. 2012, 48, 84-101. 
(10) Lovelock, C. E.; Ball, M. C.; Martin, K. C.; Feller, C. Nutrient Enrichment Increases Mortality of Mangroves. PLoS One 2009, 4, e5600.

(11) Maiti, S. K.; Chowdhury, A. Effects of Anthropogenic Pollution on Mangrove Biodiversity: A Review. J. Environ. Prot. 2013, 4, 14281434.

(12) Furukawa, K.; Wolanski, E.; Mueller, H. Currents and sediment transport in mangrove forests. Estuarine, Coastal Shelf Sci. 1997, 44, 301-310.

(13) Nissenbaum, A.; Swaine, D. J. Organic-metal interactions in recent sediments: the role of humic substances. Geochim. Cosmochim. Acta 1976, 40, 809-816.

(14) Tam, N. F. Y.; Wong, Y. S. Accumulation and distribution of heavy metals in a simulated mangrove system treated with sewage. Hydrobiologia 1997, 352, 67-75.

(15) Chakraborty, P. Speciation of $\mathrm{Co}, \mathrm{Ni}$ and $\mathrm{Cu}$ in the coastal and estuarine sediments: Some fundamental characteristics. J. Geochem. Explor. 2012, 115, 13-23.

(16) Chakraborty, P.; Ramteke, D.; Chakraborty, S. Geochemical partitioning of $\mathrm{Cu}$ and $\mathrm{Ni}$ in mangrove sediments: Relationships with their bioavailability. Mar. Pollut. Bull. 2015, 93 (1), 194-201.

(17) Chakraborty, P.; Chakraborty, S.; Jayachandran, S.; Madan, R.; Sarkar, A.; Linsy, P.; Nath, B. N. Effects of bottom water dissolved oxygen variability on copper and lead fractionation in the sediments across the oxygen minimum zone, western continental margin of India. Sci. Total Environ. 2016, 566-567, 1052-1061.

(18) Chakraborty, P.; Mason, R. P.; Jayachandran, S.; Vudamala, K.; Armoury, K.; Sarkar, A.; Chakraborty, S.; Bardhan, P.; Naik, R. Effects of bottom water oxygen concentrations on mercury distribution and speciation in sediments below the oxygen minimum zone of the Arabian Sea. Mar. Chem. 2016, 186, 24-32.

(19) Howarth, R W.; Merkel, S. (1984) Pyrite formation and the measurement of sulfate reduction in salt marsh sediments. Limnol. Oceanogr. 1984, 29, 598-608.

(20) King, G. M. Patterns of sulphate reduction and the sulphur cycle in a South Carolina salt marsh. Limnol. Oceanogr. 1988, 33, 376-90.

(21) Otero, X. L.; Ferreira, T. O.; Huerta-díaz, M. A.; Partiti, C. S. M.; Souza, V., Jr.; Vidal-Torrado, P.; Macías, F. Geochemistry of iron and manganese in soils and sediments of a mangrove system, Island of Pai Matos (Cananeia - SP, Brazil). Geoderma 2009, 148 (3-4), 318335.

(22) Noël, V.; Marchand, C.; Juillot, F.; Ona-Nguema, G.; Viollier, E.; Marakovic, G.; Olivi, L.; Delbes, L.; Gelebart, F.; Morin, G. EXAFS analysis of iron cycling in mangrove sediments downstream a lateritized ultramafic watershed (Vavouto Bay, New Caledonia). Geochim. Cosmochim. Acta 2014, 136, 211-228.

(23) Noël, V.; Morin, G.; Juillot, F.; Marchand, C.; Brest, J.; Bargar, J.; Muñoz, M.; Marakovic, G.; Ardo, S.; Brown, G. E., Jr. Ni cycling in mangrove sediments from New Caledonia. Geochim. Cosmochim. Acta 2015, 169, 82-98.

(24) Huerta-diaz, M. A.; Morse, J. W. Pyritization of trace metals in anoxic marine sediments. Geochim. Cosmochim. Acta 1992, 56, 26812702.

(25) Burton, E. D.; Sullivan, L. A.; Bush, R. T.; Powell, B. Iron-sulfide and trace element behaviour in sediments of Coombabah Lake, Moreton Bay (Australia). Mar. Pollut. Bull. 2008, 56, 1353-1358.

(26) Johnston, S. G.; Burton, E. D.; Bush, R. T.; Keene, A. F.; Sullivan, L. A.; Smith, D.; Martens, M. A.; McElnea, A. E.; Ahern, C. R.; Powell, B. Abundance and fractionation of Al, Fe and trace metals following tidal inundation of a tropical acid sulfate soil. Appl. Geochem. 2010, 25, 323-335.

(27) Johnston, S. G.; Keene, A. F.; Burton, E. D.; Bush, R. T.; Sullivan, L. A.; McElnea, A. E.; Ahern, C. R.; Smith, C. D.; Powell, B. Arsenic mobilisation in a seawater inundated acid sulfate soil. Environ. Sci. Technol. 2010, 44, 2016-2021.

(28) Burton, E. D.; Bush, R. T.; Sullivan, L. A. Fractionation and extractability of sulfur, iron and trace elements in sulfidic sediments. Chemosphere 2006, 64, 1421-1428.
(29) Nath, B.; Birch, G.; Chaudhuri, P. Trace metal biogeochemistry in mangrove ecosystems: A comparative assessment of acidified (by acid sulfate soils) and non-acidified sites. Sci. Total Environ. 2013, 463-464, 667-674.

(30) Machado, W.; Borrelli, N. L.; Ferreira, T. O.; Marques, A. G. B.; Osterrieth, M.; Guizan, C. Trace metal pyritization variability in response to mangrove soil aerobic and anaerobic oxidation processes. Mar. Pollut. Bull. 2014, 79 (1-2), 365-70.

(31) Burton, E. D.; Bush, R. T.; Sullivan, L. A.; Johnston, S. G.; Hocking, R. K. Mobility of arsenic and selected metals during reflooding of iron- and organic-rich acid-sulfate soil. Chem. Geol. 2008, $253,64-73$.

(32) Claff, S. R.; Sullivan, L. A.; Burton, E. D.; Bush, R. T.; Johnston, S. G. Partitioning of metals in a degraded acid sulfate soil landscape: Influence of tidal re-inundation. Chemosphere 2011, 85, 1220-1226.

(33) Claff, S. R.; Burton, E. D.; Sullivan, L. A.; Bush, R. T. Metal partitioning dynamics during the oxidation and acidification of sulfidic soil. Chem. Geol. 2011, 286, 146-157.

(34) Becquer, T.; Petard, J.; Duwig, C.; Bourdon, E.; Moreau, R.; Herbillon, A. J. Mineralogical, chemical and charge properties of Geric Ferralsols from New Caledonia. Geoderma 2001, 103, 291-306.

(35) Quantin, C.; Becquer, T.; Rouiller, J. H.; Berthelin, J. Oxide weathering and trace metal release by bacterial reduction in a New Caledonia Ferralsol. Biogeochemistry 2001, 53, 323-340.

(36) Dublet, G.; Juillot, F.; Morin, G.; Fritsch, E.; Fandeur, D.; Onanguema, G.; Brown, G. E., Jr. Ni speciation in a New Caledonian lateritic regolith: A quantitative $\mathrm{X}$-ray absorption spectroscopy investigation. Geochim. Cosmochim. Acta 2012, 95, 119-133.

(37) Bird, E. C. F.; Dubois, J. P.; Iltis, J. The impacts of opencast mining on the rivers and coasts of New-Caledonia. NRTS-25/UNUP 505; United Nations University Publ.: Tokyo, 1984.

(38) BRGM. Geological Map of Nouméa Feuille SF-58-XVII-1b, 2005.

(39) Virly, S. Atlas des mangroves de Nouvelle-Calédonie. Typologies et Biodiversité des mangroves de Nouvelle-Calédonie. ZoNéCo program report; Programme d'évaluation des ressources marines de la zone économique de Nouvelle-Caledonie, 2006.

(40) Song, J.; Luo, Y. M.; Zhao, Q. G.; Christie, P. Novel use of soil moisture samplers for studies on anaerobic ammonium fluxes across lake sediment - water interfaces. Chemosphere 2003, 50, 711-715.

(41) Ravel, B.; Newville, M. ATHENA, ARTEMIS, HEPHAESTUS: data analysis for X-ray absorption spectroscopy using IFEFFIT. J. Synchrotron Radiat. 2005, 12, 537-541.

(42) Winterer, M. XAFS - a data analysis program for materials science. J. Phys. IV 1997, 7 (C2), C2-243-C2-244.

(43) Dublet, G.; Juillot, F.; Morin, G.; Fritsch, E.; Noël, V.; Brest, J.; Brown, G. E., Jr. XAS Evidence for Ni Sequestration by Siderite in a Lateritic Ni-Deposit from New Caledonia. Am. Mineral. 2014, 99, 225-234.

(44) Wasserman, S. R.; Allen, P. G.; Shuh, D. K.; Bucher, J. J.; Edelstein, N. M. EXAFS and principal component analysis: a new shell game. J. Synchrotron Radiat. 1999, 6 (3), 284-286.

(45) Ressler, T.; Wong, J.; Roos, J.; Smith, I. L. Quantitative speciation of Mn-bearing particulates emitted from autos burning (methylcyclopentadienyl) manganese tricarbonyl- added gasolines using XANES spectroscopy. Environ. Sci. Technol. 2000, 34, 950-958.

(46) Webb, S. M. SIXpack: a graphical user interface for XAS analysis using IFEFFIT. Phys. Scr. 2005, T115, 1011.

(47) Malinowski, E. R. Determination of the number of factors and the experimental error in a data matrix. Anal. Chem. 1977, 49 (4), 612-617.

(48) Cancès, B.; Juillot, F.; Morin, G.; Laperche, V.; Alvarez, L.; Proux, O.; Brown, G. E., Jr.; Calas, G. XAS Evidence of As(V) Association with Iron Oxyhydroxides in a Contaminated Soil at a Former Arsenical Pesticide Processing Plant. Environ. Sci. Technol. 2005, 39, 9398-9405.

(49) Bigham, J. M.; Schwertmann, U.; Traina, S. J.; Winland, R. L.j Wolf, M. Schwertmannite and the chemical modelling of iron in acid sulphate waters. Geochim. Cosmochim. Acta 1996, 60, 2111-2121. 
(50) Cornell, R. M.; Schwertmann, U. The Iron Oxides: Structure, Properties, Reactions. Occurrences and Uses; Wiley-VCH: Darmstadt, 2003.

(51) Giblin, A. Pyrite formation in marshes during early diagenesis. Geomicrobiol. J. 1988, 6, 77-97.

(52) Lewis, M.; Pryor, R.; Wilking, L. Fate and effects of anthropogenic chemicals in mangrove ecosystems: a review. Environ. Pollut. 2011, 159, 2328-2346.

(53) Burton, E. D.; Bush, R. T.; Johnston, S. G.; Sullivan, L. A.; Keene, A. F. Sulfur biogeochemical cycling and novel $\mathrm{Fe}-\mathrm{S}$ mineralization pathways in a tidally re-flooded wetland. Geochim. Cosmochim. Acta 2011, 75 (12), 3434-3451.

(54) Burton, E. D.; Bush, R. T.; Sullivan, L. A. Sedimentary iron geochemistry in acidic waterways associated with coastal lowland acid sulfate soils. Geochim. Cosmochim. Acta 2006, 70, 5455-5468.

(55) Regenspurg, S.; Brand, A.; Peiffer, S. Formation and stability of schwertmannite in acidic mining lakes. Geochim. Cosmochim. Acta 2004, 68, 1185-1197.

(56) Carvalho-e-silva, M. L.; Ramos, A. Y.; Tolentino, H. C. N.; Enzweiler, J.; Netto, S. M.; Alves, A. M. D. C. M. Incorporation of Ni into natural goethite: an investigation by $\mathrm{X}$-ray absorption spectroscopy. Am. Mineral. 2003, 88, 876-882.

(57) Scheinost, A. C.; Sparks, D. L. Formation of layered single- and double-metal hydroxide precipitates at the mineral/ water interface. A multiple-scattering XAFS analysis. J. Colloid Interface Sci. 2000, 223 (2), 167-178.

(58) Marchand, C.; Lallier-vergès, E.; Allenbach, M. Redox conditions and heavy metals distribution in mangrove forests receiving effluents from shrimp farms (Teremba Bay, New Caledonia). J. Soils Sediments 2011, 11, 529-541.

(59) Marchand, C.; Allenbach, M.; Lallier-vergès, E. Relationships between heavy metals distribution and organic matter cycling in mangrove sediments (Conception Bay, New Caledonia). Geoderma 2011, 160, 444-456.

(60) Lambs, L.; Muller, E.; Fromard, F. The Guianese paradox: how can the freshwater outflow from the Amazon increase the salinity of the Guiana shore. J. Hydrol. 2007, 342, 88-96.

(61) Marchand, C.; Albeeric, P.; Lallier-Verges, E.; Baltzer, F. Distribution and characteristics of dissolved organic matter in mangrove sediment pore waters along the coastline of French Guiana. Biogeochemistry 2006, 81, 59-75.

(62) Ridd, P. V.; Sam, R. Profiling groundwater salt concentrations in mangrove swamps and tropical salt flats. Estuarine, Coastal Shelf Sci. 1996, 43, 627-635.

(63) Garrels, R. M.; Christ, C. L. Solution, Minerals and Equilibria; Harper \& Row: New York, 1965.

(64) Ding, H.; Yao, S.; Chen, J. Authigenic pyrite formation and reoxidation as an indicator of an unsteady-state redox sedimentary environment: Evidence from the intertidal mangrove sediments of Hainan Island, China. Cont. Shelf Res. 2014, 78, 85-99.

(65) de Souza-Junior, V. S.; Vidal-torrado, P.; Garcia-Gonzalez, M. T.; Macias, F.; Otero, X. L. Smectite in mangrove soils of the State of Sao Paulo. Sci. Agric. 2010, 67 (1), 47-52.

(66) Perrier, N.; Ambrosi, J. P.; Colin, F.; Gilkes, R. J. Biogeochemistry of a regolith: The New Caledonian Koniambo ultramafic massif. J. J. Geochem. Explor. 2006, 88 (1-3), 54-58.

(67) Johnston, S. G.; Slavich, P. G.; Hirst, P. The acid flux dynamics of two artificial drains in acid sulfate soil backswamps on the Clarence River floodplain, Australia. Aust. J. Soil Res. 2004, 42, 623-637.

(68) Macdonald, B. C. T.; Smith, J.; Keene, A. F.; Tunks, M.; Kinsela, A.; White, I. Impacts of runoff from sulfuric soils on sediment chemistry in an estuarine lake. Sci. Total Environ. 2004, 329, 115-130.

(69) Majzlan, J.; Myneni, S. C. B. Speciation of iron and sulfate in acid waters: aqueous clusters to mineral precipitates. Environ. Sci. Technol. 2005, 39, 188-194.

(70) Majzlan, J.; Navrotsky, A.; Schwertmann, U. Thermodynamics of iron oxides: Part III. Enthalpies of formation and stability of ferrihydrite $\left(\mathrm{Fe}(\mathrm{OH})_{3}\right)$, schwertmannite $\left(\mathrm{FeO}(\mathrm{OH})_{3 / 4}(\mathrm{SO} 4)_{1 / 8}\right)$, and e- $\mathrm{Fe}_{2} \mathrm{O}_{3}$. Geochim. Cosmochim. Acta 2004, 68, 1049-1059.
(71) Manceau, A.; Calas, G. Heterogeneous distribution of nickel in hydrous silicates from New Caledonia ore deposits. Am. Mineral. 1985, 70, 549-558.

(72) Butt, C. R. M.; Cluzel, D. Nickel Laterite Ore Deposits: Weathered Serpentinites. Elements 2013, 9, 123-128.

(73) Parkman, R. H.; Charnock, J. M.; Bryan, N. D.; Livens, F. R.; Vaughan, D. J. Reactions of copper and cadmium ions in aqueous solutions with goethite, lepidocrocite, mackinawite, and pyrite. Am. Mineral. 1999, 84, 407-419.

(74) Kornicker, W. A.; Morse, J. W. The interactions of divalent cations with the surface of pyrite. Geochim. Cosmochim. Acta 1991, 55, 2159-2172.

(75) Elzinga, E. J.; Sparks, D. L. Reaction condition effects on nickel sorption mechanisms in Illite-water suspensions. Soil Sci. Soc. Am. J. 2001, 65, 94-101.

(76) Xu, Y.; Axe, L.; Boonfueng, T.; Tyson, T. A.; Trivedi, P.; Pandyae, K. (2007) Ni(II) complexation to amorphous hydrous ferric oxide: An X-ray absorption spectroscopy study. J. Colloid Interface Sci. 2007, 314, 10-17.

(77) Arai, Y. Spectroscopic Evidence for Ni(II) Surface Speciation at the Iron Oxyhydroxides at Water Interface. Environ. Sci. Technol. 2008, $42,1151-1156$.

(78) Aragon, G.; Miguens, F. Microscopic analysis of pyrite in the sediments of two Brazilian mangrove ecosystems. Geo-Mar. Lett. 2001, 21, 157-161.

(79) Wong, V. N. L.; Johnston, S. G.; Burton, E. D.; Bush, R. T.; Sullivan, L. A.; Slavich, P. G. Seawater causes rapid trace metal mobilisation in coastal lowland acid sulfate soils: Implications of sea level rise for water quality. Geoderma 2010, 160, 252-263.

(80) Wong, V. N. L.; Johnston, S. G.; Burton, E. D.; Bush, R. T.; Sullivan, L. A.; Slavich, P. G. Seawater-induced mobilization of trace metals from mackinawite-rich estuarine sediments. Water Res. 2013 , $47,821-832$.

(81) Sanders, C. J.; Santos, I. R.; Maher, D. T.; Sadat-Noori, M.; Schnetger, B.; Brumsack, H.-J. Dissolved iron exports from an estuary surrounded by coastal wetlands: Can small estuaries be a significant source of Fe to the ocean? Mar. Chem. 2015, 176, 75-82.

(82) Holloway, C. J.; Santos, I. R.; Tait, D. R; Sanders, C. J.; Rose, A. L.; Schnetger, B.; Brumsack, H.-J.; Macklin, P. A.; Sippo, J. Z.; Maher, D. T. Manganese and iron release from mangrove porewaters: a significant component of oceanic budgets? Mar. Chem. 2016, 184, 4352 . 